\title{
Micronutrients Concentrations in Leaves of Oil Palm Trees Fertilized with Phosphorus, Potassium, and Magnesium
}

\author{
Ismael de Jesus Matos Viégas \\ Universidade Federal Rural da Amazônia, Brazil
}

Milton Garcia Costa, Eric Victor de Oliveira Ferreira, Eduardo do Valle Lima, Mário Lopes da Silva Júnior, Diocléa Almeida Seabra Silva

Universidade Federal Rural da Amazônia, Brazil

Received: December 14, 2020

Accepted: January 19, 2021 Published: January 25, 2021

doi:10.5296/jas.v9i1.18061

URL: https://doi.org/10.5296/jas.v9i1.18061

\begin{abstract}
The management of micronutrients in oil palm trees in the Brazilian Amazon is still underdeveloped; thus, information on plant demands and their interactions with other nutrients is required to create adequate management procedures. The objective this work was to evaluate the effects of phosphate, potassium, and magnesium fertilization on micronutrient concentrations in leaves of oil palm trees. The experiment was carried out in the Brazilian Amazon in a randomized block design in a $4 \times 2 \times 3 \times 2$ factorial scheme, using four phosphorus levels, two phosphorus sources (natural phosphate and triple superphosphate), three potassium levels and two magnesium levels. Phosphate fertilization increased the concentrations of boron, chlorine, and iron in leaves, while copper and manganese concentrations in leaves decreased with increased doses of phosphorus. Among the phosphorus sources, triple superphosphate provided higher chlorine concentrations in leaves. Potassium fertilization increased only chlorine concentrations in leaves, while magnesium supply did not alter micronutrient concentrations in leaves. Thus, phosphorus and potassium fertilizers are essential to provide adequate micronutrient concentrations in leaves of oil palm trees.
\end{abstract}

Keywords: Amazon, oleaginous, nutritional diagnosis, plant nutrition, fertilization

\section{Introduction}

Oil palm (Elaeis guineensis Jacq.) is originally from the African continent and is widely 
cultivated in tropical regions. Currently, the oil palm culture is expanding to eastern Amazon and, in the last ten years, the planted area has increased by $103.5 \%$ and bunch production by $71.5 \%$ (Ibge, 2018).

The presence of nutrients is crucial to ensure good soil quality and management, especially in agricultural ecosystems (Lopes \& Guilherme, 2007). Natural causes, such as soil genesis and weathering, are the main causes of low soil fertility, especially in tropical and subtropical regions, due to high temperatures and rainfall levels, which accelerate the leaching of nutrients (Lopes \& Guilherme, 2007). The nutrients available in tropical soils are insufficient to meet the nutritional demands of cultivated plants, requiring soil fertilization (Priyandari et al., 2017).

Micronutrients are essential elements for plants and are demanded in small amounts. They constitute part of some enzymes and are enzymatic activators in the metabolism of vegetables (Dechen et al., 2018). Although the demand for micronutrients is small, deficiencies are common in many cultivated species, which are very sensitive to changes in soil management and preparation time (Wei et al., 2006). There is little information available on micronutrients in oil palm trees, with few reports published mainly on copper $(\mathrm{Cu})$ (Pacheco et al., 1986) and boron (B) (Tohiruddin et al., 2010; Viégas et al., 2019). Matos et al., 2016 conduced a nutritional diagnosis in commercial oil palm plots in northeastern Pará State, Brazil, and indicated the $\mathrm{Mn}$ and $\mathrm{Zn}$ are the most deficient micronutrients in oil palm trees. Although some studies have evaluated micronutrient concentrations in oil palm trees in Pará State (Matos et al., 2017; Matos et al., 2019; Viégas et al., 2020), they have not investigated the effect of fertilization on micronutrient concentrations.

Micronutrients in the soil solution are constantly flowing and their concentrations depend on the ionic strength of the solution, the concentration of other ions, $\mathrm{pH}$, humidity, temperature, redox reaction, absorption by plants, as well as on addition of fertilizers (Abreu et al., 2007). The excessive use of fertilizers may have an antagonistic or synergistic action with micronutrients, requiring an understanding of responses to oil palm trees for an effective fertilization plan. In Pará State, the analysis of the soil, plant age, and crop yield recommends the use of macronutrients for the fertilization of oil palm plantations. For micronutrients, only boron is recommended (Franzini et al., 2020), although there is a suggestion of micronutrients application in the crop nutritional management plan (Matos et al., 2016).

It is necessary to investigate if fertilizations only with macronutrients and boron are sufficient to meet the demand of oil palm trees for micronutrients, since tropical soils (Lopes \& Guilherme, 2007) and the predominant cultivation of the species in the region has low chemical fertility (Franzini et al., 2017). Thus, this work evaluated the effect of $\mathrm{P}, \mathrm{K}$, and $\mathrm{Mg}$ fertilization on micronutrient concentrations in oil palm trees.

\section{Method}

The experiment was carried out at AGROPALMA® in the municipality of Tailândia, Pará State, Brazil ( $2^{\circ} 56^{\prime} 50^{\prime \prime} \mathrm{S}$ and $\left.48^{\circ} 57^{\prime} 12^{\prime \prime} \mathrm{W}\right)$. The climate in the region is rainy tropical without seasonal thermal variation with a relative humidity of $84 \%$ (Köppen classification). During 


\section{Macrothink}

the study period, the temperature ranged from 21 to $32.5{ }^{\circ} \mathrm{C}$ and the average annual precipitation was $2,463 \mathrm{~mm}$. During the experiment, rainfall was measured using a rain gauge installed in the experimental area (Figure 1).

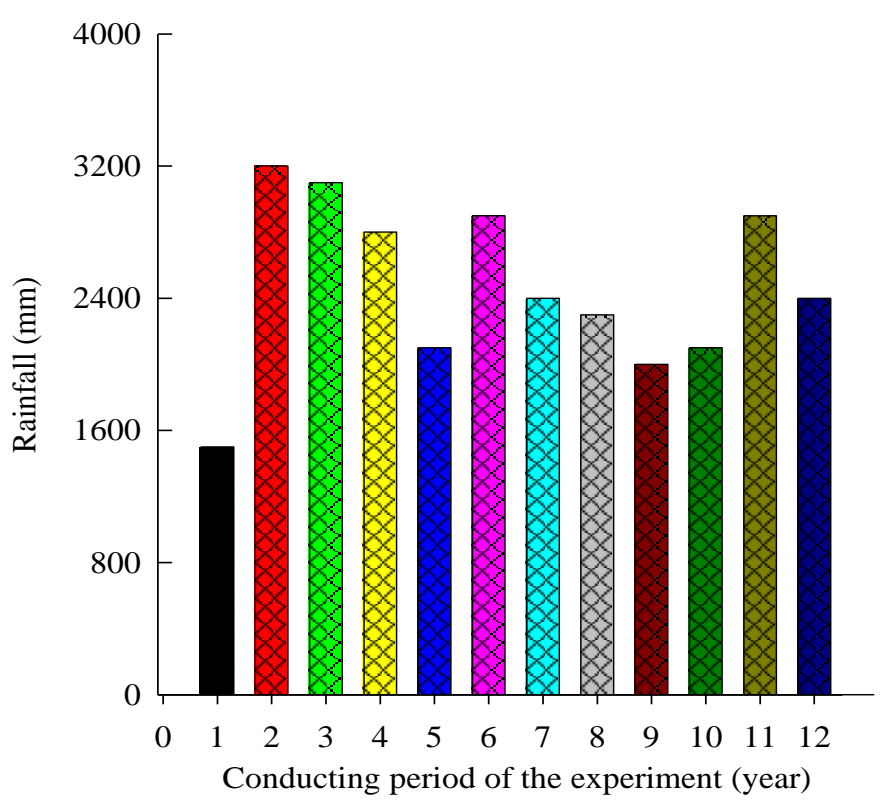

Figure 1. Rainfall (mm) during the experiment period at AGROPALMA®

The municipality of Tailândia has a predominance of dystrophic Yellow Latosol, acidic, with low natural chemical fertility (Rodrigues et al., 2005). Before the installation of the experiment, soil texture ( $610 \mathrm{~g} \mathrm{~kg}^{-1}$ of sand, $150 \mathrm{~g} \mathrm{~kg}^{-1}$ of silt, and $240 \mathrm{~g} \mathrm{~kg}^{-1}$ of clay) was evaluated $(0-0.3 \mathrm{~m})$ and classified as sandy loam. The soil chemical features $(0-0.3 \mathrm{~m})$ were also evaluated (Table 1). The chemical and texture of the soil were carried out at the Institut de Recherches pour les Huiles et Oléagineux.

Table 1. Soil chemical features $(0-0.3 \mathrm{~m})$ in the study site before experiment implementation

\begin{tabular}{|c|c|c|c|c|c|c|c|}
\hline $\mathrm{pH}$ & $\mathrm{SOM}^{* *}$ & $P_{\text {total }}$ & $\mathrm{P}_{\text {available }}{ }^{*}$ & $\mathrm{~K}^{*}$ & $\mathrm{Ca}^{+2 *}$ & $\mathrm{Mg}^{+2^{*}}$ & $\mathrm{Al}^{+3}$ \\
\hline$\left(\mathrm{H}_{2} \mathrm{O}\right)$ & $\mathrm{g} \mathrm{kg}^{-1}$ & \multicolumn{3}{|c|}{------------ $\mathrm{mg} \mathrm{dm}^{-3}$----------- } & \multicolumn{3}{|c|}{---------cmolc $\mathrm{dm}^{-3}$----- } \\
\hline 5.20 & 16.4 & 89 & 12 & 15.6 & 2.38 & 0.50 & 0.02 \\
\hline
\end{tabular}

Note. * extracted with ion exchange resin. ** colorimetric method. SOM - Soil Organic Matter.

The experiment site was prepared with the removal of natural vegetation and the burning of plant residues. The swath was mechanized and every six rows of oil palm trees formed a windrow. The soil was covered at the beginning of the experiment between the planting rows with the cultivation of legumes [Pueraria phaseoloides (Roxb. Benth.), Calopogonium mucunoídes Desv. and Pubescens pubescens Benth]. 
The experimental design comprised randomized blocks in a factorial scheme $4 \times 2 \times 3 \times 2$ with four levels of $\mathrm{P}$, two sources of $\mathrm{P}$, three levels of $\mathrm{K}$, and two levels of $\mathrm{Mg}$. The sources of $\mathrm{P}, \mathrm{K}$, and $\mathrm{Mg}$ used were triple superphosphate $\left(45 \% \mathrm{P}_{2} \mathrm{O}_{5}\right.$ and $\left.10 \% \mathrm{OCa}\right)$ and phosphine (natural phosphate; $33 \% \mathrm{P}_{2} \mathrm{O}_{5}$ and $\left.42 \% \mathrm{OCa}\right)$, potassium chloride $\left(60 \% \mathrm{~K}_{2} \mathrm{O}\right.$ and $\left.47 \% \mathrm{Cl}\right)$ and magnesium sulfate $(18 \% \mathrm{Mg})$, respectively (Table 2).

Table 2. Doses, source, and time (years) of fertilizers application used in the treatments

\begin{tabular}{|c|c|c|c|c|c|c|c|c|c|c|c|c|c|}
\hline \multirow{3}{*}{ Year } & \multicolumn{8}{|c|}{ Sources of $\mathrm{P} * *\left(\mathrm{~g}\right.$ plant $\left.^{-1}\right)$} & \multirow{2}{*}{\multicolumn{3}{|c|}{$\mathrm{KCl}\left(\mathrm{g}_{\text {plant }}{ }^{-1}\right)$}} & \multirow{2}{*}{\multicolumn{2}{|c|}{$\begin{array}{c}\mathrm{MgSO}_{4}(\mathrm{~g} \\
\left.\text { plant }^{-1}\right)\end{array}$}} \\
\hline & \multicolumn{4}{|c|}{ F0 } & \multicolumn{4}{|c|}{$\mathrm{F} 1$} & & & & & \\
\hline & $\mathrm{P}_{1}$ & $\mathrm{P}_{2}$ & $\mathrm{P}_{3}$ & $\mathrm{P}_{4}$ & $\mathrm{P}_{1}$ & $\mathrm{P}_{2}$ & $\mathrm{P}_{3}$ & $\mathrm{P}_{4}$ & $\mathrm{~K}_{0}$ & $\mathrm{~K}_{1}$ & $\mathrm{~K}_{2}$ & $\mathrm{Mg}_{0}$ & $\mathrm{Mg}_{1}$ \\
\hline $0^{*}$ & 250 & 500 & 700 & 1000 & 200 & 400 & 600 & 800 & 0 & 300 & 450 & 0 & 300 \\
\hline 1 & 250 & 500 & 750 & 1000 & 200 & 400 & 600 & 800 & 0 & 500 & 750 & 0 & 500 \\
\hline 2 & 250 & 500 & 750 & 1000 & 200 & 400 & 750 & 800 & 0 & 1000 & 1500 & 0 & 1000 \\
\hline 3 & 250 & 500 & 750 & 1000 & 200 & 400 & 600 & 800 & 0 & 1500 & 2250 & 0 & 1000 \\
\hline 4 & 250 & 500 & 750 & 1000 & 200 & 400 & 600 & 800 & 0 & 2000 & 3000 & 0 & 1000 \\
\hline 5 & 250 & 625 & 1000 & 1375 & 200 & 500 & 800 & 1100 & 0 & 1500 & 3000 & 0 & 1000 \\
\hline 6 to 12 & 250 & 750 & 1250 & 1750 & 200 & 600 & 1000 & 1400 & 0 & 1600 & 3200 & 0 & 1200 \\
\hline
\end{tabular}

Note. * Over $300 \mathrm{~kg} \mathrm{ha}^{-1}$ of acidulated natural phosphate throughout the area; $* * \mathrm{~F}_{\mathrm{o}}=$ Phosphine $\left(33 \% \mathrm{P}_{2} \mathrm{O}_{5}\right.$ and $\left.42 \% \mathrm{OCa}\right)$ and $\mathrm{F}_{1}=$ Triple superphosphate $\left(45 \% \mathrm{P}_{2} \mathrm{O}_{5}\right.$ and $10 \%$ $\mathrm{OCa})$.

Before the experiment installation, $300 \mathrm{~kg} \mathrm{ha}^{-1}$ of partially acidulated natural phosphate $(27 \%$ of $\mathrm{P}_{2} \mathrm{O}_{5}$ ) was applied uniformly throughout the experiment site. In all treatments, between the first and the third year of cultivation, were applied doses of 150, 300, and $500 \mathrm{~g} \mathrm{plant}^{-1}$ of urea. We also applied $100 \mathrm{~g} \mathrm{plant}^{-1}$ of borax in fifth year of cultivation.

The genetic material used was hybrid DELI x La Mé (Category C), obtained from the LaMé research station of the Institut de Recherches pour les Huiles et Oléagineux. Oil palm seedlings were produced and conducted for six months in a pre-nursery and later transferred to the nursery, remaining for another three months until planting in the field. The spacing used was an equilateral triangle of nine meters in quincunx $(9 \mathrm{~m}$ between plants and $7.80 \mathrm{~m}$ between lines) for 143 plants ha ${ }^{-1}$. The experimental plot consisted of six lines, and each line had nine plants; however, only twelve central plants were evaluated. 
The concentrations of micronutrients $(\mathrm{B}, \mathrm{Cl}, \mathrm{Cu}, \mathrm{Fe}, \mathrm{Mn}$, and $\mathrm{Zn}$ ) in leaves were evaluated, based on the chemical analyses carried out in the plant laboratory of the Institut de Recherches pour les Huiles et Oléagineaux (IRHO). Except for the twelfth year, which was carried out at the Department of Soil Sciences of the Federal University of Lavras (UFLA), according to the method described in Sarruge and Haag (1974). For that purpose, leaf 17 was collected from all plants in each useful plot, and leaf 9 was collected in cases of absence of leaf 17 (Veloso et al., 2020). The $\mathrm{Cl}$ concentration in leaves was determined from the third to the sixth year, while B concentration in leaves was determined in the third, fifth, sixth, and twelfth year. The concentration of $\mathrm{Cu}, \mathrm{Fe}, \mathrm{Mn}$, and $\mathrm{Zn}$ were determined only in the twelfth year of age of the plants. The nutrient concentrations were determined by the method of azomethine $\mathrm{H}(\mathrm{B})$, titration of silver nitrate $(\mathrm{Cl})$ and atomic absorption spectrophotometry $(\mathrm{Cu}, \mathrm{Fe}, \mathrm{Mn}$ and $\mathrm{Zn})$.

The results were subjected to the analysis of variance (ANOVA) and compared using the Tukey test $(\mathrm{p}<0.05)$ for $\mathrm{P}$ sources and $\mathrm{K}$ and $\mathrm{Mg}$ levels, while the regression models were adjusted for P levels using the Sisvar statistical software (Ferreira, 2011).

\section{Results and Discussion}

The B concentrations in leaves responded quadratically to the increase in $\mathrm{P}$ fertilization (Figures 2a, 2b, and 2c). Viégas et al. (2019) and Tohiruddin et al. (2010) also observed n increase in B concentration in leaves of oil palm due to $\mathrm{P}$ application in the conditions in Pará and in Indonesia, respectively. The estimated $\mathrm{P}$ doses that provided the highest concentrations of $\mathrm{B}$ were 439 and $477 \mathrm{~g}_{\text {plant }}{ }^{-1}$ of $\mathrm{P}_{2} \mathrm{O}_{5}$, reaching concentrations of 24.9 and $21.7 \mathrm{mg} \mathrm{kg}^{-1}$ of $\mathrm{B}$, respectively, in young plants (3 to 6 years) and in adult plants (12 years) (Figure 2).

Boron is found in the soil solution as boric acid at neutral $\mathrm{pH}$, forming a complex with $\mathrm{Ca}$ or combining with soluble organic compounds (Dechen et al., 2018). This explains the increase of $\mathrm{B}$ concentrations in leaves with an increase in $\mathrm{P}$ fertilization, since $\mathrm{P}$ sources contain $\mathrm{Ca}$ $(\mathrm{F} 0=42 \% \mathrm{OCa} ; \mathrm{F} 1=10 \% \mathrm{OCa})$, allowing greater formation of $\mathrm{B}$ complexes in the soil solution, reducing the effect of leaching, and increasing nutrient uptake by plants (Figures $2 \mathrm{a}$, $2 \mathrm{~b}$, and $2 \mathrm{c})$.

The B concentration in leaves of oil palm trees did not respond significantly to $\mathrm{P}$ sources in the years evaluated (Figure 2d). Matos et al. (2016) carried out a study with oil palm in eastern Amazon and determined the critical concentration of $24.3 \mathrm{mg} \mathrm{kg}^{-1}$ of B for young plants $(<6$ years of age) and of $22.7 \mathrm{mg} \mathrm{kg}^{-1}$ of B for adult plants ( $\geq 6$ years old). Thus, B concentrations in leaves reached the critical level determined for the crop with both sources of $\mathrm{P}$ applied only in the twelfth year of the plant crop. Recently, there is recommendation for B application to oil palm (Franzini et al., 2020); however, Viégas and Botelho (2010) recommend the application of $10 \mathrm{~g} \mathrm{plant}^{-1}$ of FTE BR 12 (1.8\% of B). In our study, fertilization with B (11 g plant ${ }^{-1}$ ) was carried out only in the fifth year of cultivation, which possibly had a prolonged residual effect of the nutrient, since there was an increase of B concentrations in leaves only in the twelfth year (Figures 2d, 2e, and 2f). Even though the region is more susceptible to B losses due to leaching (Figure 1), the B source applied (borax) has low solubility $\left(20 \mathrm{~g} \mathrm{~L}^{-1}\right)$ (Ferreira et al., 2020), which may have contributed to its greater residual effect. 


\section{Macrothink Institute ${ }^{\text {TM }}$}

According to Abreu et al. (2007), high precipitation levels and a high degree of losses, due to leaching, decrease B availability, especially in sandy soils. In general, B is linked to soil organic matter (SOM) in surface layers, making SOM mineralization an essential B source for plants (Dechen et al., 2018). The low B concentrations in leaves observed in our study may be attributed to high precipitation levels (Figure 1), sandy soil texture, acidic pH, and low SOM concentration (Table 1). Besides, there was a lack of fertilization with B in most years of cultivation, despite the use of legumes as a soil cover, such as Pueraria, which can cycle approximately $180 \mathrm{~g} \mathrm{ha}^{-1}$ year $^{-1}$ of $\mathrm{B}$ in oil palm plantations from the second to the eighth year of age (Perez, 1997; Viégas et al., 2018).

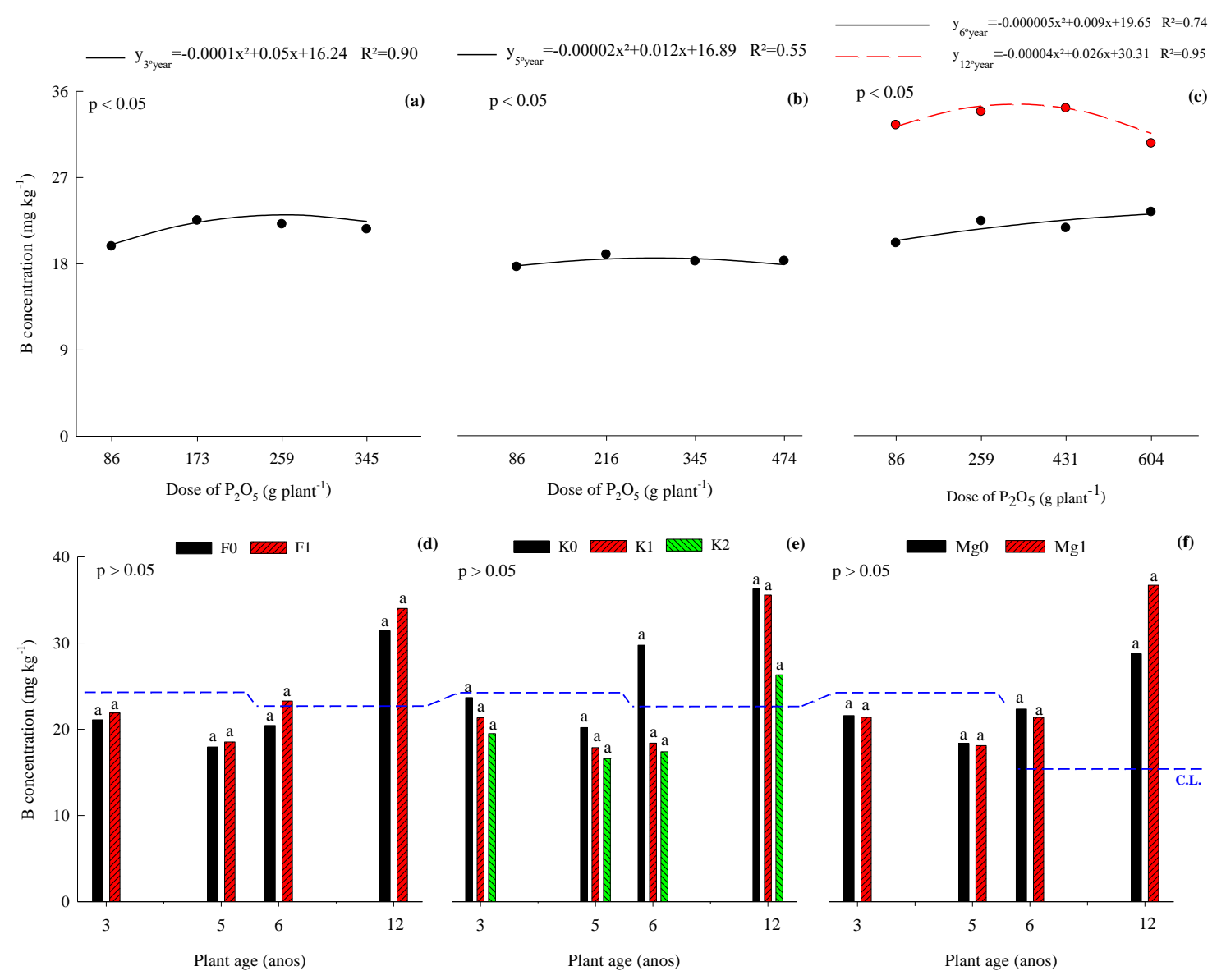

Figure 2. B concentrations in oil palm leaves as a function of $\mathrm{P}$ doses in the third (a), fifth (b), sixth and twelfth years (c) of plant age, $\mathrm{P}$ sources (F0 - phosphine and F1- triple superphosphate) (d), and the doses of $\mathrm{K} \mathrm{(e)} \mathrm{and} \mathrm{Mg}$ (f). Equal letters in the columns, comparing $\mathrm{P}$ sources and fertilization levels of $\mathrm{K}$ and $\mathrm{Mg}$ at each age of the plants, are considered statistically equal by the Tukey test ( $p>0.05$ ). C.L. - Critical level established for oil palm in Pará by the method of reduced normal distribution (RND) (Matos et al., 2016)

Fertilization with $\mathrm{K}$ and $\mathrm{Mg}$ on oil palm showed no significant effects on B concentrations in the leaves (Figures 2e and 2f). Viégas et al. (2019) studied oil palm in eastern Amazon and reported no significant effect of $\mathrm{P}$ and $\mathrm{Mg}$ fertilization on $\mathrm{B}$ concentrations in leaves. The crown formation of oil palm trees has the greatest demand for B and crown formation reaches 
its peak in the fifth year after planting, followed by a slow in vegetative growth, due to competition between plants (Goh et al., 2007). However, Viégas (1993) investigated the extraction of nutrients in oil palm plantations in Pará State and found that the greatest demand for B occurred in the eighth year. Moreover, in sites with adult plants, litterfall contributes to the cycling of $17.7 \mathrm{~g}$ leaf $^{-1}$ of B (Goh et al., 2007), favoring B supply to oil palm.

Although the levels of $\mathrm{K}$ fertilization showed no significant difference, $\mathrm{B}$ concentrations in leaves tended to decrease with an increase in K supply (Figure 2e), corroborating with the literature (Tohiruddin et al., 2010; Viégas et al., 2019). Studies show that $\mathrm{K}$ fertilization decreases B absorption in oil palm plants (Rajarattnam, 1973). The oil palm culture is a major consumer of $\mathrm{KCl}$ and high rates of $\mathrm{K}$ fertilizer induce B deficiency (IPPI, 1989). Thus, there is an antagonistic relationship between $\mathrm{Cl}$ and $\mathrm{B}$. Although it is more retained in the soil than colloids (Abreu et al., 2007), high concentrations of Cl- in the soil solution, depending on the application of high $\mathrm{KCl}$ doses, could promote greater $\mathrm{B}$ desorption, increasing the leaching of $\mathrm{B}$ by mass effect and decreasing its absorption by plants (Figure $2 \mathrm{e}$ ).

The $\mathrm{Cl}$ concentrations in leaves responded to $\mathrm{P}$ application in a quadratic way in the third and fourth years (Figure 3a) and in a positive linear way in the fifth and sixth years (Figures 3b and $3 \mathrm{c}$ ). The average concentration of $\mathrm{Cl}$ increased proportionally with the doses of $\mathrm{P}$, with an increase of 5.1 to $5.8 \mathrm{~g} \mathrm{~kg}^{-1}$ and even higher leaf concentrations of this nutrient were observed at the sixth year in relation to the other evaluated years (5.6 to $6.2 \mathrm{~g} \mathrm{~kg}^{-1}$ of Cl) (Figure 3). Viégas et al. (2019) also observed an increase in the $\mathrm{Cl}$ concentrations in leaves of oil palm with increased $\mathrm{P}$ doses. Oil palm tends to increase the absorption of $\mathrm{Cl}$ during its development to nourish the formation of new tissues (Viégas et al., 2020), which may be related to the vegetative growth provided by increased P doses (Viégas et al., 2019), boosting the demand for $\mathrm{Cl}$ in the formation of new palm oil tissues.

Among the $\mathrm{P}$ sources evaluated, $\mathrm{Cl}$ concentrations were higher in leaves when $\mathrm{P}$ was supplied through triple superphosphate (Figure 3d). Triple superphosphate is considered a source of faster P release (Alcarde, 2007), unlike phosphine (natural phosphate). Phosphate ions are retained more strongly than chloride in soil colloids (Novais et al., 2007); thus, greater desorption and greater absorption of $\mathrm{Cl}$ by plants were observed with $\mathrm{P}$ application via triple superphosphate. To date, the critical level of $\mathrm{Cl}$ in oil palm has not been defined and optimal levels for $\mathrm{Cl}$ concentrations in leaves range between 5 and $7 \mathrm{~g} \mathrm{~kg}^{-1}$ (Uexkull \& Fairhust 1991). Viégas et al. (2020) reported $\mathrm{Cl}$ concentrations in leaves between 3 and $5 \mathrm{~g} \mathrm{~kg}^{-1}$ in oil palm trees from 2 to 8 years old in eastern Amazon. In our study, it appears that the $\mathrm{Cl}$ concentrations in leaves remained within the variation presented in the literature.

Possibly, $\mathrm{Cl}$ is not only involved in cellular osmoregulation in structural tissues of palm trees, but also in the regulation of stomatal opening (Dubos et al., 2011). This fact justifies the high $\mathrm{Cl}$ concentration in palm trees compared to other cultivated plants, which usually have $\mathrm{Cl}$ concentration around $0.1 \mathrm{~g} \mathrm{~kg}^{-1}$ (Chen et al., 2010), indicating the importance of this nutrient for oil palm trees.

Fertilization with $\mathrm{K}$ showed that the $\mathrm{Cl}$ concentrations in leaves increased with the supply of 
$\mathrm{KCl}$; however, there was no difference between the fertilization levels (Figure 3e). Other studies have reported the same behavior for oil palm trees in (Dubos et al., 2011; Viégas et al., 2019). The synergistic response of $\mathrm{Cl}$ to $\mathrm{K}$ supply is explained by the $\mathrm{Cl}$ content (47\%) in the composition of $\mathrm{K}$ fertilizer. $\mathrm{Cl}$ is mobile and easily leached into the soil; therefore, crops grown in soils with a low $\mathrm{Cl}$ concentration, such as sandy loam and sandy soils, have greater benefit from the application of Cl-source fertilizers, with more positive responses (Chen et al., 2010). The soil in our study site is loam-sandy, which may have augmented the response of the $\mathrm{Cl}$ concentrations in leaves, mainly under high rainfall levels that occurred in the region during the experiment period (Figure 1).

Fertilization with $\mathrm{Mg}$ did not alter the $\mathrm{Cl}$ concentration in leaves of oil palm trees (Figure $3 \mathrm{f}$ ). Daniel \& Ochs (1975) carried a study with young oil palm trees and reported that the application of $\mathrm{Mg}$ sulfate did not cause a significant response to the $\mathrm{Cl}$ concentrations in leaves. Viégas et al. (2019) carried out a study in eastern Amazon and did not find a beneficial effect of $\mathrm{Mg}$ fertilization on $\mathrm{Cl}$ concentrations in leaves of oil palm trees. Thus, $\mathrm{Mg}$ supply does not alter the $\mathrm{Cl}$ concentrations in leaves of oil palm trees.

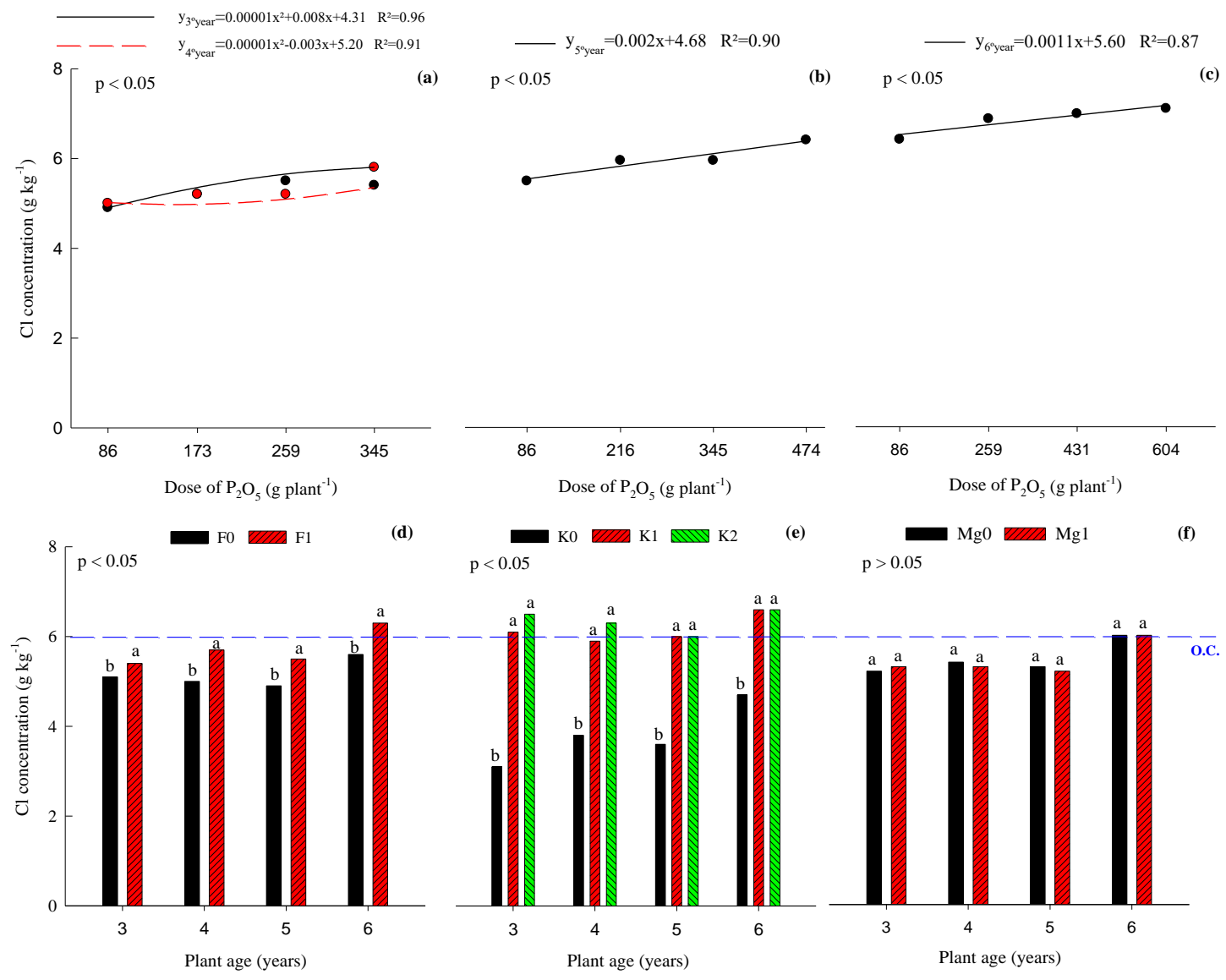

Figure 3. $\mathrm{Cl}$ concentrations in oil palm leaves as a function of $\mathrm{P}$ doses in the third and fourth (a), in the fifth (b), in the sixth years (c) of plant age, P sources (F0 - phosphine and F1- triple superphosphate) (d), and the doses of $\mathrm{K}$ (e) and $\mathrm{Mg}$ (f). Equal letters in the columns, comparing $\mathrm{P}$ sources and fertilization levels of $\mathrm{K}$ and $\mathrm{Mg}$ at each age of the plants, are considered statistically equal by the Tukey test ( $p>0.05)$. O.C. - Optimal $\mathrm{Cl}$ concentration 
established for oil palm (Uexkull and Fairhust 1991).

The $\mathrm{Cu}$ concentrations in leaves showed a quadratic response to the $\mathrm{P}$ doses applied (Figure 4a). The leaf $\mathrm{Cu}$ concentration decreased proportionally with the increase in $\mathrm{P}$ doses from 7.1 to $6.2 \mathrm{mg} \mathrm{kg}^{-1}$ of $\mathrm{Cu}$ (Figure 4a). Tohiruddin et al. (2010) conducted a study in Indonesia and found similar results, with an antagonistic effect between the $\mathrm{Cu}$ concentrations in leaves and $\mathrm{P}$ fertilization in oil palm plantations. Studies carried out in other perennial crops have also indicated an antagonistic effect between $\mathrm{Cu}$ and the applications of $\mathrm{P}$ fertilizers, which may even lead to $\mathrm{Cu}$ deficiency, due to high $\mathrm{P}$ doses (Dechen et al., 2018).

On the other hand, $\mathrm{P}$ sources did not influence the $\mathrm{Cu}$ concentration in leaves of oil palm trees (Figure $4 \mathrm{~b}$ ). Likewise, $\mathrm{K}$ and $\mathrm{Mg}$ fertilization did not alter $\mathrm{Cu}$ concentrations in leaves (Figure $4 \mathrm{~b}$ ). Studies carried out in Indonesia with $\mathrm{K}$ fertilization in oil palm trees also found no significant response to $\mathrm{Cu}$ concentrations in leaves (Tohiruddin et al., 2010).

In oil palm orchards in northeastern Pará, Matos et al. (2016) determined the critical concentration of $5.2 \mathrm{mg} \mathrm{kg}^{-1}$ of $\mathrm{Cu}$ for young plants and $5.0 \mathrm{mg} \mathrm{kg}^{-1}$ of $\mathrm{Cu}$ for adult plants. In our study, $\mathrm{Cu}$ concentrations in leaves are above the critical level for plantations in the region. Besides, the use of legumes as ground cover may have contributed to the greater cycling of $\mathrm{Cu}$. Viégas et al. (2018) carried out a study with Pueraria phaseoloides L. and reported a cycling of $15 \mathrm{~g} \mathrm{ha}^{-1}$ of $\mathrm{Cu}$ at the eighth year of age of plants, increasing $\mathrm{Cu}$ concentration in the soil solution, with greater $\mathrm{Cu}$ absorption by the oil palm tree.
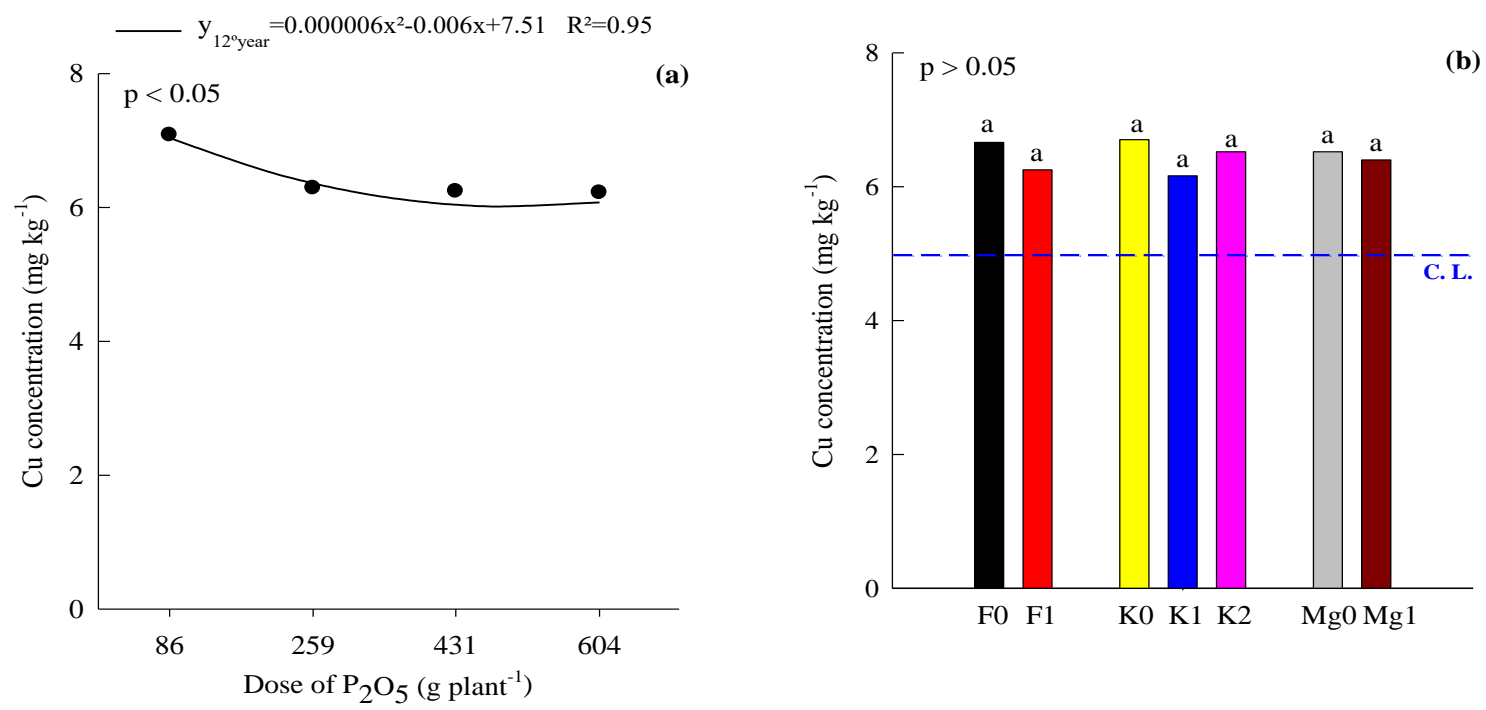

Figure 4. $\mathrm{Cu}$ concentrations in oil palm leaves as a function of $\mathrm{P}$ doses (a), P sources (F0 phosphine and F1- triple superphosphate) and $\mathrm{K}$ and $\mathrm{Mg}$ doses (b) in the twelfth year of the plant age. Equal letters in the columns, comparing $\mathrm{P}$ sources and fertilization levels of $\mathrm{K}$ and $\mathrm{Mg}$, are considered statistically equal by the Tukey test ( $>>0.05)$. C.L. - Critical level established for oil palm in Pará by the method of reduced normal distribution (RND) (Matos et al., 2016).

The Fe concentrations in leaves responded quadratically to the P doses applied (Figure 5a). In our study, the estimated $\mathrm{P}$ dose that provided the highest leaf concentration of $\mathrm{Fe}\left(88 \mathrm{mg} \mathrm{kg}^{-1}\right)$ 
was $516 \mathrm{~g} \mathrm{plant}^{-1}$ of $\mathrm{P}_{2} \mathrm{O}_{5}$ (Figure $5 \mathrm{a}$ ). Fe deficiency is usually caused by the imbalance between micronutrients, mainly by the excess of $\mathrm{Mn}, \mathrm{Cu}$, and $\mathrm{Mo}$ (Abreu et al., 2007). Dechen et al. (2018) reported that $\mathrm{Cu}$ excess could lead to Fe deficiency, since $\mathrm{Cu}$ acts in reactions that affect the oxidation state of $\mathrm{Fe}$, limiting its absorption and translocation in plants. Thus, the plants showed low Fe concentrations (Figure 5b) probably due to an indirect effect of high $\mathrm{Cu}$ concentrations in leaves (Figure 4b). Because the Yellow Latosols contain high Fe levels (Costa \& Bigham, 2019), higher absorption of Fe could be expected due to their advanced weathering degree. In these soils, oxidation reactions are predominant due to good aeration and thus the prevalence of the $\mathrm{Fe}^{+3}$ trivalent form, but the $\mathrm{Fe}^{+2}$ form is preferentially absorbed by plants (Dechen, 2018). However, high rainfall levels in the plantation areas of the region (Figure 1), in addition to possible soil compaction, may also have contributed to the reduction of $\mathrm{Fe}^{+3}$ to $\mathrm{Fe}^{+2}$, favoring the increase of $\mathrm{Fe}$ absorption by plants. Furthermore, Fe solubility decreases with the increase in $\mathrm{pH}$, possibly decreasing to a thousand times with each increase in the $\mathrm{pH}$ of the soil, within the range from 4 to 9 (Abreu et al., 2007).

The sources of $\mathrm{P}, \mathrm{K}$, and $\mathrm{Mg}$ fertilization did not influence the Fe concentration in the leaves in oil palm trees (Figure $5 \mathrm{~b}$ ). The $\mathrm{P}$ and $\mathrm{K}$ fertilization in oil palm trees did not significantly affect the Fe concentrations in leaves (Tohiruddin et al., 2010). In eastern Amazon, the critical concentration of $86.9 \mathrm{mg} \mathrm{kg}^{-1}$ of Fe was determined for young plants and $85.8 \mathrm{mg} \mathrm{kg}^{-1}$ of Fe for adult plants (Matos et al., 2016). Deficiency of Fe in cultivated plants has been observed due to the action of metal nutrients, such as $\mathrm{Cu}, \mathrm{Zn}$ and $\mathrm{Co}$, which are capable of replacing Fe in the soil chelates and hindering its availability (Dechen et al., 2018).

The Fe availability is generally low considering the nutritional demand in aerated soils and a neutral $\mathrm{pH}$, with greater availability of $\mathrm{Fe}$ in the soil solution with acidic $\mathrm{pH}$ (Abreu et al., 2007), similar to the soil $\mathrm{pH}$ of our study (Table 1). However, even under greater acidity, plants did not present Fe concentrations considered adequate for the crop (Figure 5b). Viégas (1993) found that the greatest extraction of Fe by oil palm organs occurred in the eighth year, corresponding to $17 \mathrm{~kg} \mathrm{ha}^{-1}$ of $\mathrm{Fe}$. Plants require $\mathrm{Fe}$ at high quantities, which act on the physiological activities of plants, such as electron transport, cytochrome, chlorophyll biosynthesis, and enzymatic activation (Prado, 2020). 

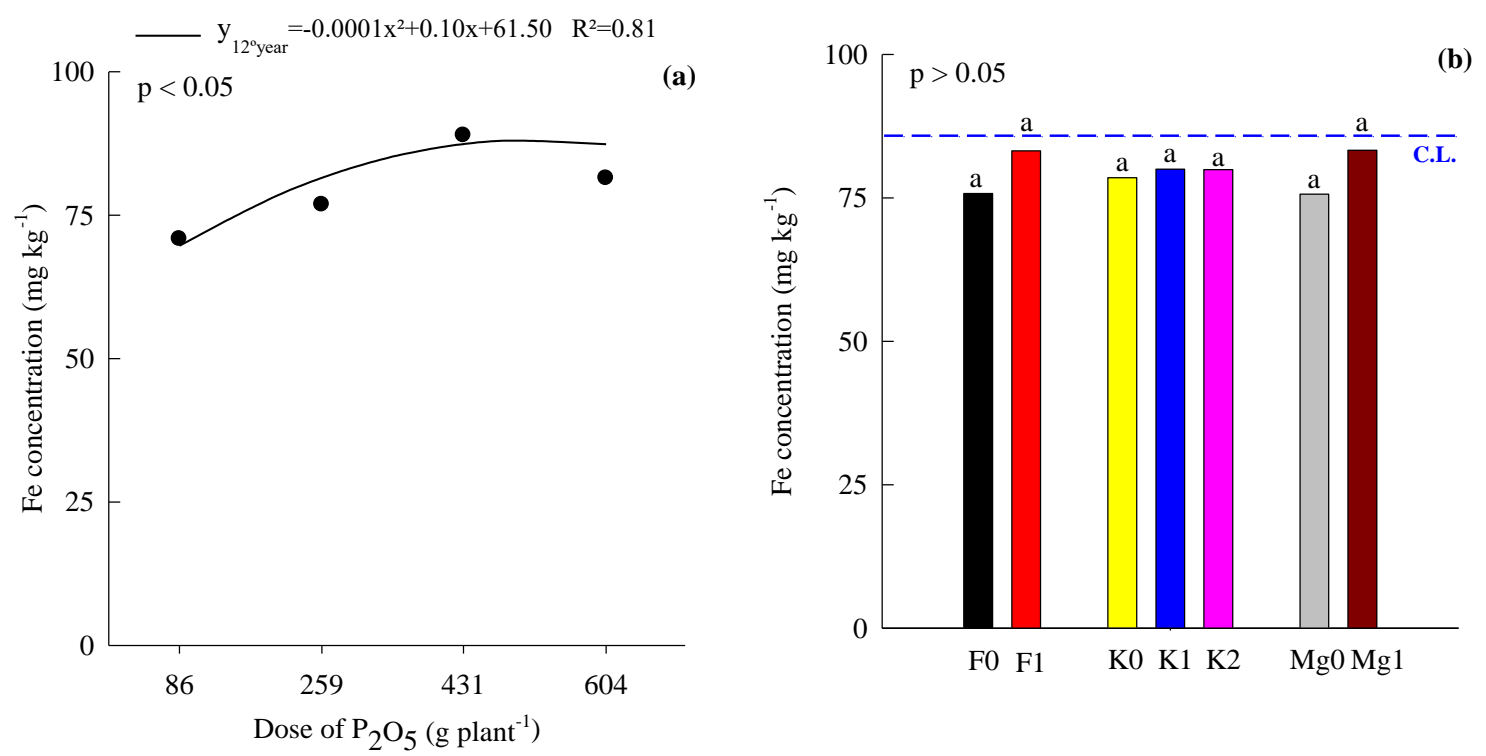

Figure 5. Fe concentration in oil palm leaves trees as a function of $\mathrm{P}$ doses (a), $\mathrm{P}$ sources (F0 phosphine and F1- triple superphosphate) and $\mathrm{K}$ and $\mathrm{Mg}$ doses (b) in the twelfth year of the plant age. Equal letters in the columns, comparing $\mathrm{P}$ sources and fertilization levels of $\mathrm{K}$ and $\mathrm{Mg}$, are considered statistically equal by the Tukey test ( $>>0.05)$. C.L. - Critical level established for oil palm in Pará using the reduced normal distribution method (RND) (Matos et al., 2016).

The Mn concentrations in leaves responded in a quadratic manner, with a decrease from 499 to $415 \mathrm{mg} \mathrm{kg}^{-1}$ of Mn with increasing of $\mathrm{P}$ doses (Figure 6a). The Ca excess in the soil can cause Mn deficiency (Abreu et al., 2007), explaining that increased $\mathrm{P}$ doses led to an antagonistic effect with $\mathrm{Ca}$, since $\mathrm{P}$ fertilizers contain $\mathrm{Ca}$ in their composition (Table 2). In addition, the $\mathrm{Ca}$ concentration in the soil (Table 1) was in the medium level of availability in our study (Brasil \& Cravo, 2020).

The critical Mn concentrations in oil palm cultivated in the Amazon were established at 258 $\mathrm{mg} \mathrm{kg}^{-1}$ for young plants and $244 \mathrm{mg} \mathrm{kg}^{-1}$ for adult plants (Matos et al., 2016). Although the Mn concentrations in leaves decreased with the reduction of $\mathrm{P}$ supply, they remained above the critical level established for the crop (Figure 6a). Viégas (1993) obtained Mn concentration of $224 \mathrm{mg} \mathrm{kg}^{-1}$ in leaves of oil palm from 2 to 8 years of age, below the critical level suggested by Matos et al. (2016) and the levels obtained in our study.

The Mn concentrations in leaves of oil palm trees did not respond significantly to $\mathrm{P}$ sources and $\mathrm{K}$ and $\mathrm{Mg}$ fertilization (Figure 6b). Tohiruddin et al. (2010) carried out a study with K fertilization and did not obtain a significant response in $\mathrm{Mn}$ concentrations in leaves of oil palm trees. Although the difference was not significant, there was a tendency towards a lower concentration of $\mathrm{Mn}$ in leaves with $\mathrm{K}$ and $\mathrm{Mg}$ fertilization. Luyindula \& Batanga (2017) investigated different oil palm genotypes and found a negative correlation between $\mathrm{K}$ and $\mathrm{Mn}$ concentrations in leaves. In addition, the excess of $\mathrm{Mg}$ and Fe can cause $\mathrm{Mn}$ deficiency in cultivated plants (Abreu et al., 2007). In this sense, our results corroborate with the literature, 
indicating an antagonistic effect between $\mathrm{K}$ and $\mathrm{Mg}$ applications and $\mathrm{Mn}$ absorption. The assessment of critical ranges of nutrients in commercial oil palm plots in Pará State showed that $\mathrm{Mn}$ and $\mathrm{Zn}$ displayed the highest deficiency in plants (Matos et al., 2016).
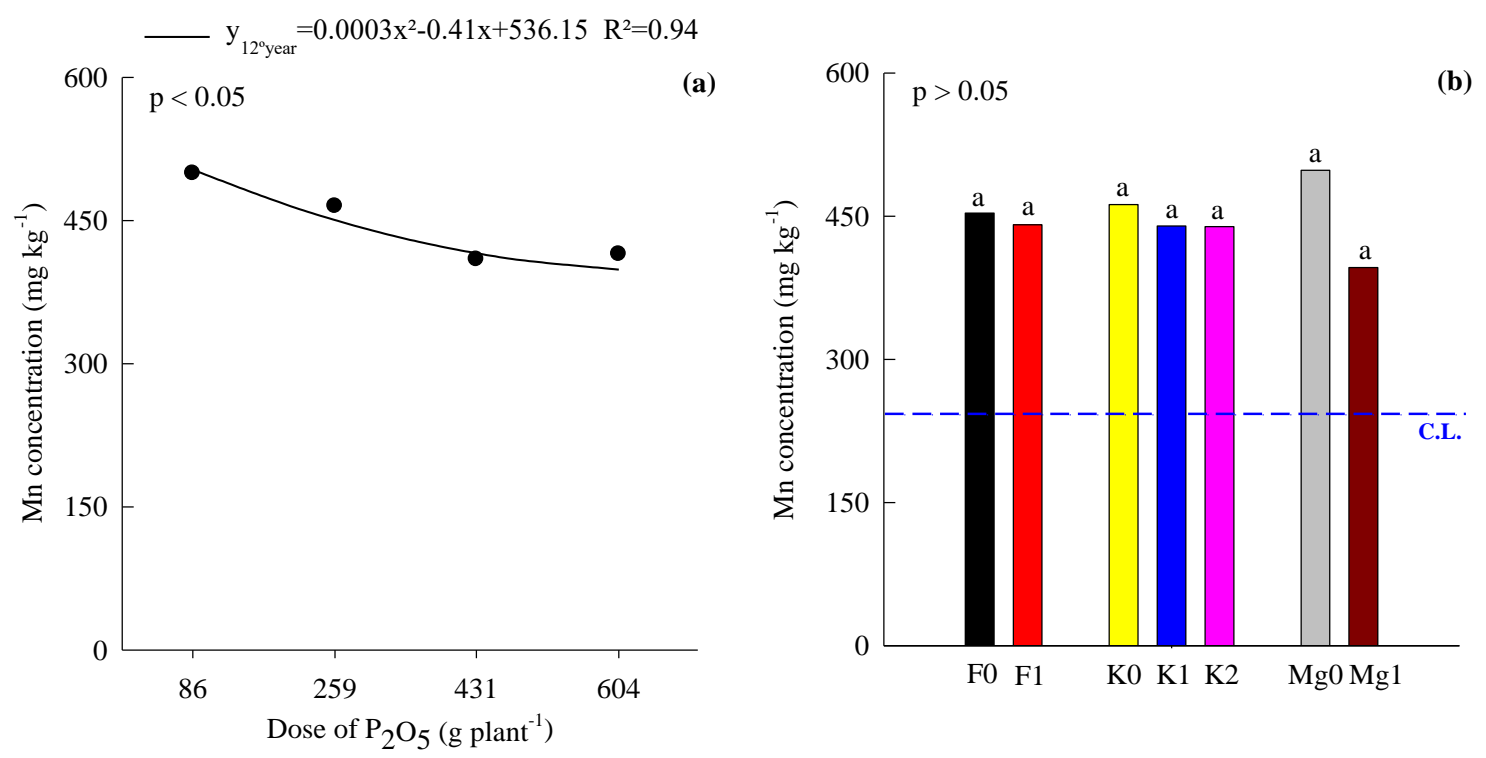

Figure 6. Mn concentrations in oil palm leaves as a function of P doses (a), P sources (F0 phosphine and F1- triple superphosphate) and $\mathrm{K}$ and $\mathrm{Mg}$ doses (b) in the twelfth year of the plant age. Equal letters in the columns, comparing $\mathrm{P}$ sources and fertilization levels of $\mathrm{K}$ and $\mathrm{Mg}$, are considered statistically equal by the Tukey test ( $\mathrm{p}>0.05)$. C.L. - Critical level established for oil palm in Pará using the reduced normal distribution method (RND) (Matos et al., 2016).

The $\mathrm{Zn}$ concentrations did not respond significantly to the $\mathrm{P}$ doses applied to oil palm trees, with a variation in leaf concentration from 14.4 to $16.8 \mathrm{mg} \mathrm{kg}^{-1}$ of $\mathrm{Zn}$ (Figure 7a). In Indonesia, Tohiruddin et al. (2010) reported that $\mathrm{N}$ and $\mathrm{P}$ fertilization decreased the $\mathrm{Zn}$ concentrations in leaves of young oil palm trees, with no effect on older plants, similar to our results. Leaves were sampled only in the twelfth year of age of the plants to determine the $\mathrm{Zn}$ concentrations. Although $\mathrm{P}$ application did not influence $\mathrm{Zn}$ absorption (Figure 7a), the antagonism between these nutrients is reported in the literature (Abreu et al., 2007; Dechen et al., 2018) in which high $\mathrm{P}$ doses could cause $\mathrm{Zn}$ deficiency. In the Brazilian Amazon, Ochs and Corrado (1985) made the first reports of visual symptoms of Zn deficiency in oil palm in the edaphoclimatic conditions of Manaus, Amazonas State, Brazil. This nutritional disorder is mainly attributed to the application of high doses of $\mathrm{P}$ fertilizer, in addition to $\mathrm{Zn}$ deficiency in soils. According to Singh and Moller (1984), the levels of available $\mathrm{Zn}$ ranged from 0.05 to $0.24 \mathrm{mg} \mathrm{kg}^{-1}$ in Yellow Latosols.

Furthermore, $\mathrm{P}$ sources and fertilization with $\mathrm{K}$ and $\mathrm{Mg}$ showed no significant effect on $\mathrm{Zn}$ concentrations in oil palm leaves (Figure 7b). Tohiruddin et al. (2010) investigated K fertilization in oil palm trees and reported effect on $\mathrm{Zn}$ concentrations in leaves and only a trend of lower $\mathrm{Zn}$ concentrations at high $\mathrm{K}$ doses was found, similar to our study (Figure 7a). 
Luyindula and Batanga (2017) evaluated the effect of different palm oil genetics and found a negative correlation between the $\mathrm{K}$ and $\mathrm{Zn}$ concentrations in leaves. The critical $\mathrm{Zn}$ concentrations in leaves of oil palm are $15.4 \mathrm{mg} \mathrm{kg}^{-1}$ in young plants and $15.5 \mathrm{mg} \mathrm{kg}^{-1}$ in adult plants (Matos et al., 2016). Viégas (1993) assessed the extraction of nutrients in oil palm trees from 2 to 8 years of age and found $\mathrm{Zn}$ concentrations that ranged from 9.7 to 23 $\mathrm{mg} \mathrm{kg} \mathrm{in}^{-1}$ the leaflets, similar to the range of concentrations in our study. On average, $\mathrm{Zn}$ concentrations in leaves were below the critical level, indicating the need to replace the nutrient through fertilization to increase its concentrations in leaves of oil palm plants.
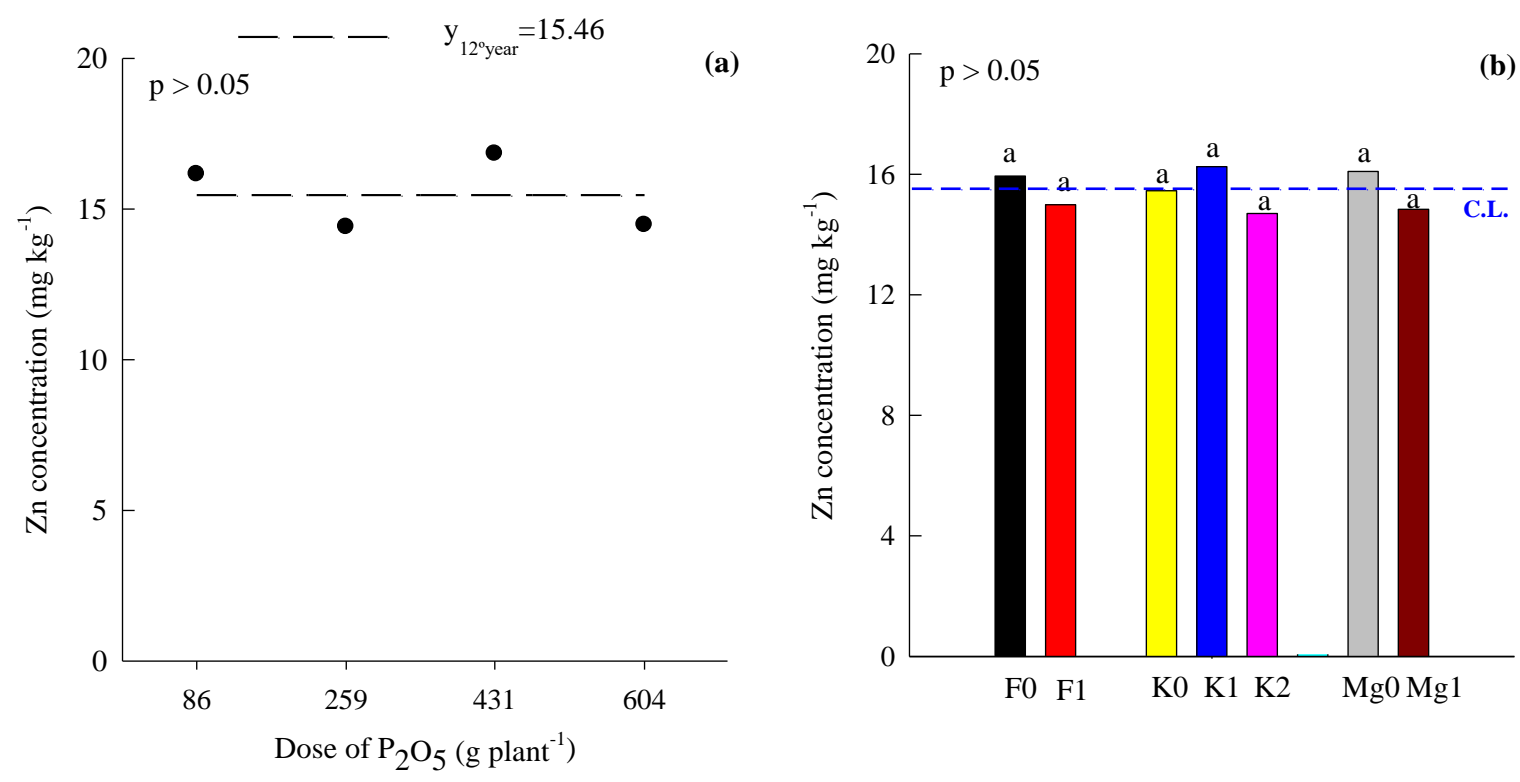

Figure 7. Zn concentration in oil palm leaves as a function of P doses (a), P sources (F0 phosphine and F1- triple superphosphate) and $\mathrm{K}$ and $\mathrm{Mg}$ doses (b) in the twelfth year of plant age. Equal letters in the columns, comparing $\mathrm{P}$ sources and fertilization levels of $\mathrm{K}$ and $\mathrm{Mg}$, are considered statistically equal by the Tukey test ( $p>0.05$ ). C.L. - Critical level established for oil palm in Pará by the method of reduced normal distribution (RND) (Matos et al., 2016).

\section{Conclusion}

The triple superphosphate and natural phosphate sources did not influence the nutrition of micronutrients in oil palm trees, except for $\mathrm{Cl}$ concentrations in leaves, which increased with the supply of triple superphosphate, resulting in synergism.

Phosphorus fertilization improves the nutrition of oil palm trees in term of $\mathrm{B}, \mathrm{Cl}$, and $\mathrm{Fe}$; however, it decreases $\mathrm{Cu}$ and $\mathrm{Mn}$ concentrations in leaves.

Potassium fertilization improves $\mathrm{Cl}$ nutrition, while $\mathrm{Mg}$ supply does not affect leaf micronutrient concentrations in oil palm plants.

Regardless of the mineral fertilization carried out in adult plants, oil palm plants were well-nourished in terms of $\mathrm{B}, \mathrm{Cl}, \mathrm{Cu}$, and $\mathrm{Mn}$; however, $\mathrm{Fe}$ and $\mathrm{Zn}$ nutrition was not satisfactory. 


\section{Acknowledgements}

We thank to Embrapa Amazônia Oriental for the support given to this research and to Agropalma company by it offers its areas for this study. We also thank to researchers Robert Ochs, Francis Corrado, Abílio Pacheco and Sonia Botelho for the help provided.

\section{References}

Abreu, C. A., Lopes, A. S., \& Santos, G. C. G. (2007). Micronutrientes. In R. F. Novaes, V. H. Alvarez, N. F., Barros, \& J. C. L. Neves (Eds.), Fertilidade do Solo (pp. 645-736). Viçosa: Sociedade Brasileira de Ciência do Solo.

Alcarde, J. C. (2007). Fertilizantes. In R. F. Novaes, V. H. Alvarez, N. F. Barros, \& J. C. L. Neves (Eds.), Fertilidade do Solo (pp. 737-768). Viçosa: Sociedade Brasileira de Ciência do Solo.

Brasil, E. C., \& Cravo, M. S. (2020). Interpretação dos resultados da análise do solo. In E. C. Brasil, M. S. Cravo, \& I. de J. M. Viégas (Eds.), Recomendações de calagem e adubação para o estado do Pará (2rd ed.) (pp. 61-64). Brasília: Embrapa.

Chen, W., He, Z. L., Yang, X. E., Mishra, S., \& Stoffella, P. J. (2010). Chlorine nutrition of higher plants: progress and perspectives. Journal of Plant Nutrition, 33(7), 943-952. https://doi.org/10.1080/01904160903242417

Costa, A. C. S., \& Bigham, J. M. (2019). Óxidos de ferro. In V. F. Melo, \& L. R. F. Alleoni, (Eds.), Química e Mineralogia do Solo: conceitos básicos e aplicações (pp. 505-572). Viçosa: Sociedade Brasileira de Ciência do Solo.

Daniel, C., \& Ochs, R. (1975). Amélioration de la production des jeunes palmiers à huile du Pérou par l'emploi d'engrais chloré. Olégineux, 30(7), 295-298.

Dechen, A. R., Nachtigall, G. R., Carmello, Q. A. C., Santos, L. A., \& Sperandio, M. V. L. (2018). Micronutrientes. In M. S. Fernandes, S. R. Souza, \& L. A. Santos (Eds.), Nutrição Mineral de Plantas (pp. 492-562). Viçosa: Sociedade Brasileira de Ciência do Solo.

Dubos, B., Alarcón, W. H., López, J. E., \& Ollivier, J. (2011). Potassium uptake and storage in oil palm organs: the role of chlorine and the influence of soil characteristics in the Magdalena valley, Colombia. Nutrient cycling in agroecosystems, 89(2), 219-227. https://doi.org/10.1007/s10705-010-9389-X

Ferreira, C. P., Cravo, M. S., \& Ferreira, E. V. O. (2020). Fertilizantes minerais. In E. C. Brasil, M. S. Cravo, \& I. de J. M. Viégas (Eds.), Recomendações de calagem e adubação para o estado do Pará (2rd ed.) (pp. 73-92). Brasília: Embrapa.

Ferreira, D. F. (2011). Sisvar: a computer statistical analysis system. Ciência e agrotecnologia, 35(6), 1039-1042. https://doi.org/10.1590/S1413-70542011000600001

Franzini, V. I., Matos, G. S. B., Machado, D. N., Assunção, E. A., Viégas, I. de J. M., \& Botelho, S. M. (2020). Palma de óleo (Dendezeiro). In E. C. Brasil, M. S. Cravo, \& I. de J. M. Viégas (Eds.), Recomendações de calagem e adubação para o estado do Pará (2rd ed.) (pp. 
279-282). Brasília: Embrapa.

Franzini, V. I., Souza, M. B., Gomes Junior, R. A., Silva, A. R. B., \& Rodrigues, E. C. F. (2017). Fertilidade do solo, nutrição e desenvolvimento vegetativo da palma de óleo consorciada com culturas alimentares. Belém: Embrapa Amazônia Oriental. p. 31.

Goh, K. J., Gan, H. H., Kee, K. K., Chew, P. S.; \& Teoh, K. C. (2007). Boron requirement and distribution in the oil palm (Elaeis guineensis Jacq.) and some implications on manuring practices. In: F. Xu, H. E. Goldbach, P. H. Brown, R. W. Bell, T. Fujiwara, C. D. Hunt, S. Goldberg, L. Shi (eds.), Advances in Plant and Animal Boron Nutrition (pp. 189-202). Dordrecht: Springer.

Ibge (Instituto brasileiro de geografia e estatística). (2018). Pesquisa agrícola municipal. Disponível in: https://www.ibge.gov.br/estatisticas/economicas/agricultura-e-pecuaria/9117producao-agricola-municipal-culturastemporarias-e-permanentes.html? =\&t=resultados.Acces sed in 25 set. 2020.

Ippi (International plant problem insights). (1989). Potassium and boron deficiencies in oil palm. Potash a Phosphate Institute (PPI): Atlanta.

Lopes, A. S., \& Guilherme, L. R. G. (2007). Fertilidade do solo e produtividade agrícola. In R. F. Novaes, V. H. Alvarez, N. F. Barros, \& J. C. L. Neves (Eds.), Fertilidade do Solo (pp. 1-64). Viçosa: Sociedade Brasileira de Ciência do Solo.

Luyindula, N. Z., \& Batanga, R. (2017). Nutrient contents of young oil palm trees as affected by genetic materials, including some inbred progenies. International Journal of Research in Agricultural Sciences, 4(1), 61-65.

Matos, G. S. B. D., Fernandes, A. R., \& Wadt, P. G. S. (2016). Níveis críticos e faixas de suficiência de nutrientes derivados de métodos de avaliação do estado nutricional da palma-de-óleo. Pesquisa Agropecuária Brasileira, 51(9), 1557-1567. https://doi.org/10.1590/s0100-204x2016000900055

Matos, G. S. B. D., Fernandes, A. R., Wadt, P. G. S., Pina, A. J. D. A., Franzini, V. I., \& Ramos, H. M. N. (2017). The use of DRIS for nutritional diagnosis in oil palm in the state of Pará. Revista Brasileira de Ciência do Solo, 41(1), e0150466. https://doi.org/10.1590/18069657rbcs20150466

Matos, G. S. B., Rodrigues, G. R., Gama, M. A. P., Galvão, J. R., Viégas, I. de J. M., \& Neto, A. A. L. M. (2019). Compositional nutrient diagnosis in two oil palm genetic materials. Revista Ibero-Americana de Ciências Ambientais, 10(6), 1-5. https://doi.org/10.6008/CBPC2179-6858.2019.006.0001

Novais, R. F., Smyth, T. J., \& Nunes, F. N. (2007). Fósforo. In R. F. Novaes, V. H. Alvarez, N. F. Barros, \& J. C. L. Neves (Eds.), Fertilidade do Solo (pp. 471-550). Viçosa: Sociedade Brasileira de Ciência do Solo.

Ochs, R., \& Corrado, F. (1985). Researchs agronomiques et application au development de l aculture du palmier à huile au Bresil. Paris: CIRAD/IRHO, 1985. p. 59. 
Pacheco, A. R., Barnwell, I. M., \& Tailliez, B. (1986). Des cas de déficience en cuivre en pépinières de palmiers à huile en Amazonie brésilienne. Oleagineux, 41(11), 483- 489.

Perez, P. N. L. (1997). Crescimento, concentração e conteúdo de nutrientes em Pueraria phaseoloides L. com dois anos a oito anos de idade em Latossolo Amarelo distrófico, Tailândia, Pará. Dissertação de mestrado, Faculdade de Ciências Agrárias do Pará, Belém.

Prado, R. de M. (2020). Nutrição de plantas (2rd ed.). Jaboticabal: Editora UNESP, 2020. 416p.

Priyandari, Y., Zakaria, R., \& Syakura, A. (2017). Sistem Pakar Pemupukan Kelapa Sawit Menggunakan Metode Forward Chaining. Performa: Media Ilmiah Teknik Industri, 16(2), 98-106. https://doi.org/10.20961/performa.16.2.16978

Rajaratnam, J. A. (1973). Movement and accumulation of boron in some Malaysian Soils. Experimental Agriculture, 9(3), 233-240. https://doi.org/10.1017/S0014479700005755

Rodrigues, T. E., Silva, J. M. L., Silva, B. N. R., Valente, M., Gama, J., Santos, E. S., Rollim, P. A. M., \& Ponte, F. C. (2005). Caracterização e classificação dos solos do município de Tailândia, estado do Pará. Belém: Embrapa Amazônia Oriental.

Sarruge, J. R., Haag, H. P. (1974). Análises químicas em plantas. Piracicaba: ESALQ. p. 56.

Singh, R. \& Moller, M. R. F. (1984). Disponibilidade de micronutrientes em classes dominantes de solos do Trópico Úmido brasileiro. II. Manganês. EMBRAPA-CPATU. Boletim de pesquisa.

Tohiruddin, L., Tandiono, J., Silalahi, A. J., Prabowo, N. E., \& Foster, H. L. (2010). Effects of N, P and K fertilizers on leaf trace element levels of oil palm in Sumatra. Journal of Oil Palm Research, 22(12), 869-877.

Uexkull, H. V., \& Fairhust, T.H. (1991). Fertilizing for hight yield and quality: The oil palm. International Potash Institute. IPI Bull., 12, 1-79.

Veloso, C. A. C., Botelho, S. M., Viégas, I. de J. M., \& Rodrigues, J. E. L. F. (2020). Amostragem e diagnose foliar. In E. C. Brasil, M. S. Cravo, \& I. de J. M. Viégas (Eds.), Recomendações de calagem e adubação para o estado do Pará (2rd ed.) (pp. 65-72). Brasília: Embrapa.

Viégas, I, de J. M.; \& Botelho, S.M. (2007). Dendezeiro. In M. S. Cravo, I. de J. M. Viégas, \& E. C. Brasil, (Eds..), Recomendações de adubações e calagem para o estado do Pará (pp. 205-206). Brasília: Embrapa.

Viégas, I. de J. M., Galvão, J. R., dos SANTOS, C. R. C., Silva, D. A. S., Sodré, D. C., \& de FREITAS, J. M. N. (2018). Micronutrients content in Pueraria phaseoloides L. on soils under oil palm plantations in Tailândia, state of Pará. Bioscience Journal, 34(1), 59-66. https://doi.org/10.14393/BJ-v34n1a2018-36398

Viégas, I. de J. M., Galvão, J. R., da Silva, A. O., da Conceição, H. E. O., Pacheco, M. J. B., Viana, T. C., ... \& Silva, D. A. S. (2020). Chlorine Nutrition of Oil Palm Tree (Elaeis Guinq 
Jacq) in Eastern Amazon. Journal of Agricultural Studies, 8(3), 704-720. https://doi.org/10.5296/jas.v8i3.16243

Viégas, I. de J. M., de Oliveira Pimentel, M. J., Galvão, J. R., Silva, D. A. S., Ferreira, E. V. O., Silva Junior, M. L., Yakuwa, T. K. M., \& Lima, S. K. D. S. (2019). Adubação mineral na fase produtiva da palma óleo (Elaeis guineenses jacq) cultivada na região Amazônica. Revista Ibero-Americana de Ciências Ambientais, 10(6), 274-286. https://doi.org/10.6008/CBPC2179-6858.2019.006.0024

Viégas, I. de J. M. (1993). Crescimento do dendezeiro (Elaeis guineensis Jacq.), concentração, conteúdo e exportação de nutrientes nas diferentes partes de plantas com 2 a 8 anos de idade, cultivadas em Latossolo Amarelo distrófico, Tailândia-Pará. Tese de Doutorado, Escola Superior de Agricultura Luiz de Queiroz, Universidade de São Paulo, Piracicaba, SP, Brazil.

Wei, X., Hao, M., Shao, M., \& Gale, W. J. (2006). Changes in soil properties and the availability of soil micronutrients after 18 years of cropping and fertilization. Soil and Tillage Research, 91(1-2), 120-130. https://doi.org/10.1016/j.still.2005.11.009

\section{Copyright Disclaimer}

Copyright for this article is retained by the author(s), with first publication rights granted to the journal.

This is an open-access article distributed under the terms and conditions of the Creative Commons Attribution license (http://creativecommons.org/licenses/by/4.0/). 